Magdalena Homa

ORCID: 0000-0003-1735-5150

Uniwersytet Wrocławski

Monika Mościbrodzka

ORCID: 0000-0002-3987-8246

Uniwersytet Wrocławski

https://doi.org/10.19195/1733-5779.32.10

\title{
Ocena efektywności inwestycji w fundusze inwestycyjne w kontekście zaburzenia symetrii rozkładu
}

JEL Classification: C10, E44, G11

Słowa kluczowe: efektywność, miary klasyczne i alternatywne, fundusze inwestycyjne

Keywords: efficiency, classic and alternative measures, investment funds

Abstrakt: Wiedza na temat ryzyka i efektywności ma istotne znaczenie dla wszystkich uczestników giełdy, to jest klientów, inwestorów i podmiotów gospodarczych; dostarcza ona niezbędnych informacji pomocnych w podjęciu decyzji, w które walory, w danym momencie, warto ulokować kapitał, aby przy jak najmniejszym ryzyku wygenerować jak największy zysk. Najpowszechniejszymi miernikami stosowanymi przez zarządzających są tak zwane klasyczne miary ryzyka i efektywności, jednak prawidłowe wnioskowanie na ich podstawie wymaga spełnienia założenia o normalności (log normalności) rozkładu stóp zwrotu. Dlatego też w pracy, po pierwsze, zbadano rozkład stóp zwrotu wybranych FI o zróżnicowanej strategii inwestycyjnej, a następnie zweryfikowano wpływ odejścia od normalności rozkładu na zasadność zastosowania miar alternatywnych. Dodatkowo $\mathrm{w}$ artykule poddano weryfikacji tezę, czy pozycje rankingowe funduszy zależą od przyjętych wskaźników efektywności. W konsekwencji okazało się, że rankingi tworzone na podstawie wykorzystanych wskaźników klasycznych oraz alternatywnych opartych na semiodchyleniu prowadzą do podobnych wniosków o efektywności w przeciwieństwie do tak zwanych miar, badających relację zysków do strat. 


\title{
The assessment of investment efficiency in investment funds in the context of asymmetry of distribution
}

\begin{abstract}
Knowledge about risk and efficiency is important for all stock market participants, i.e. customers, investors, and business entities. It provides the necessary information helpful in making decisions about assets in which we may invest capital to generate the highest possible profit with minimal risk. The most common measures used by managers are the so-called classic measures of risk and efficiency, however, correct inference based on them requires meeting the assumption of normality (log normality) of the distribution of rates of return. Therefore, the work first examined the distribution of rates of return of selected IF with a diversified investment strategy, and then verified the impact of departing from the normality of the distribution on the justification for using alternative measures. In addition, the article verifies the thesis whether the ranking positions of the funds depend on the adopted performance indicators. As a consequence, it turned out that the rankings created on the basis of the used classic and alternative indicators based on semi-bias lead to similar conclusions on effectiveness as opposed to the so-called measures examining the relation of profits to losses.
\end{abstract}

\section{Wprowadzenie}

Jedną z możliwości inwestowania, dostępną na rynku, są inwestycje w fundusze inwestycyjne, które uważane są za jedną z bezpieczniejszych form pomnażania kapitału. Według ekspertów podstawowa zasada inwestowania w ten instrument mówi, że im bardziej ryzykowna jest strategia inwestycyjna funduszu, tym dłuższy powinien być horyzont inwestycyjny. Stąd też, przykładowo, w prospektach funduszy akcji minimalny, zalecany czas trwania inwestycji to najczęściej pięć lat; dla funduszy obligacji sugeruje się natomiast inwestowanie przez nie mniej niż dwa lata. Wybór odpowiedniego funduszu nie jest jednak łatwym zadaniem - dlatego eksperci inwestycyjni radzą, aby przed podjęciem decyzji zastanowić się, jakie ryzyko jest się w stanie ponieść i jak długo planuje się oczekiwać na realizację celów inwestycyjnych. Mianowicie ci inwestorzy, którzy są skłonni zaryzykować więcej w zamian za perspektywę wyższych wyników, powinni skorzystać z potencjału rynku akcji. Osoby, które cenią bezpieczeństwo, mogłyby raczej rozważyć inwestycje w obligacje lub fundusze pieniężne ${ }^{1}$. Poszukiwanie nowych możliwości lokowania nadwyżki finansowej stawia zatem przed inwestorami konieczność dokonywania pogłębionych analiz w zakresie zwrotu zainwestowanego kapitału. Wyniki tych analiz dają informację na temat historycznych efektów funduszy inwestycyjnych. Należy podkreślić, że zagadnienia metod oceny inwestycji w aktywa finansowe są szeroko opisywane w piśmiennictwie zagranicznym i krajowym. Niezależnie od klasyków teorii portfela (H. Markowitz, J. Tobin, W. Sharpe, J.L. Treynor, J. Lintner, J. Mossin, S. Ross) wśród autorów należy wymienić także R. Haugena, E.J. Eltona i M.J. Grubera,

\footnotetext{
${ }^{1}$ https://www.analizy.pl/fundusze/edukacja/jak-inwestowac/19107/ile-tak-naprawde-mozemy-zarobic-na-funduszach-inwestycyjnych.html (dostęp: 1.02.2020).
} 
F.K. Reilly’ego i K.C. Browna. W piśmiennictwie polskim z kolei — głównie K. i T. Jajugów i W. Tarczyńskiego. Aby poprawnie dokonać wyboru sposobu inwestowania, należy przed wszystkim dokonać analizy funduszy pod kątem ich efektywności. Takie badania zostały wielokrotnie wykonywane nie tylko odnośnie do polskiego rynku $\mathrm{FI}^{2}$, ale również do rynków zagranicznych ${ }^{3}$. W analizach tych wykorzystywane były klasyczne miary, oparte na odchyleniu standardowym i stopie zwrotu z premii za ryzyko, czy też dodatkowej stopie zwrotu.

Ocena efektywności aktywów kapitałowych zgodnie z klasycznymi miarami wiąże się jednak z pewnymi ograniczeniami poprawności zastosowania, które wynikają z niespełnienia założenia o normalności (log-normalności) rozkładu stóp zwrotu lub przynajmniej ich symetryczności. W takiej sytuacji odchylenie standardowe oraz miary efektywności na nim oparte stają się nieadekwatne. W związku z powyższym w artykule poddano analizie efektywność inwestycji w FI polskiego rynku — zarówno w krótkim, jak i w długim okresie inwestycyjnym, przy założeniu ,pasywnej” postawy inwestora, to znaczy przy założeniu, że inwestor inwestuje w dany fundusz inwestycyjny, nie zmieniając go przez cały okres objęty badaniem.

W artykule zweryfikowano rozkład stóp zwrotu i, biorąc pod uwagę widoczną asymetrię rozkładów stóp zwrotu, wykazano, że w analizach ryzyka i efektywności badanych FI polskiego rynku należy uwzględnić alternatywne miary zróżnicowania oparte na semiodchyleniu. Oprócz tego zweryfikowano, czy zastosowano dodatkowe miary efektywności, co było celem badania.

\section{Badanie efektywności na polskim rynku funduszy inwestycyjnych — przegląd literatury}

Najczęściej stosowanymi metodami badania efektywności funduszy inwestycyjnych są te, które przeprowadzane zostają z poziomu stóp zwrotu oraz ryzyka. Wówczas oceny efektywności dokonuje się na podstawie stworzonych rankingów, w których zajęta pozycja odpowiada poziomowi wartości wykorzystanych miar efektywności. W tym przypadku wysokie pozycje w rankingu oznaczają ponadprzeciętne wyniki, natomiast niskie pozycje — słabe. Główną wadą tworzenia i porównywania rankingów jest fakt, że efektywność funduszy określa się tylko w relacji do innych funduszy lub portfeli rynkowych. Można stwierdzić zatem, że ocena efektywności funduszy inwestycyjnych sprowadza się do określenia rodzaju

2 Przykładowo K. Jurek-Wasilewska, Efektywność inwestowania w otwartych funduszach inwestycyjnych w Polsce w latach 2001-2010, „Finanse i Prawo Finansowe” 2014, s. 20-33.

3 Przykładowo M. Grinblatt, S. Titman, Mutual Fund Performance: An Analysis of Quarterly Portfolio Holdings, „The Journal of Business” 62, 1989, nr 3, s. 393-416, DOI: 10.1086/296468; S.J. Kon, F.C. Jen, The investment performance of mutual funds: an empirical investigation of timing, selectivity, and market efficiency, „The Journal of Business” 52, 1979, nr 2, s. 263-289, DOI: $10.1086 / 296046$. 
i poziomu ryzyka, które towarzyszy lokowaniu aktywów funduszy oraz wartości uzyskanych stóp zwrotu i porównania do danego portfela rynkowego. Używając tej metody, należy mieć na uwadze punkt referencyjny, tak zwany benchmark, którym nie musi być portfel wzorcowy, lecz może być nim na przykład wartość zero. Może też się okazać, że najlepszym funduszem jest ten, który osiągnął najniższą stratę w badanej grupie ${ }^{4}$.

W praktyce najczęściej metody te dzieli się na dwie grupy — klasyczne i alternatywne. W badaniach dotyczących efektywności polskich funduszy inwestycyjnych wyraźnie widoczne są dwa nurty badawcze. W pierwszym z nich wykorzystuje się współczynniki Sharpe'a ${ }^{5}$, Treynora ${ }^{6}$ i alfę Jensena ${ }^{7}$ oraz ich modyfikacje, takie jak współczynnik alfa Sharpe’a, wskaźnik informacyjny IR oraz wskaźnik Modiglianich. W przypadku tych metod nacisk kładzie się na ryzyko całkowite i rynkowe oraz umiejętności zarządzających w zakresie selekcji instrumentów finansowych. Cechą charakterystyczną tych metod jest założenie o neutralnym traktowaniu ryzyka. Zestaw trzech miar efektywności był wykorzystywany w pionierskich analizach efektywności krajowych funduszy inwestycyjnych w pracach T. Miziołka ${ }^{8}$, który badaniu poddał fundusze funkcjonujące w 1999 roku oraz fundusze akcyjne i zrównoważone w 2000 roku, a zaproponowany zestaw miar efektywności stał się podstawą badań innych autorów 9 . Z kolejnych, klasycznych, miar skorzystali J. Czekaj, M. Woś i J. Żarnowski ${ }^{10}$, którzy — oprócz wskaźników Sharpe’a, Treynora i alfy Jensena - wykorzystali w badaniu współczynnik alfa

${ }^{4}$ T. Miziołek, A.A. Trzebiński, Efektywność polskich funduszy inwestycyjnych - przeglad metod $i$ literatury, http://knfpan.pan.pl/images/Fin._110-17_6-T.Miziolek_i_in.pdf (dostęp: 23.02.2020).

5 W.F. Sharpe, Mutual Fund Performance, ,Journal of Business” 39, 1966, nr 1, s. 119-138.

6 J.L. Treynor, How to rate management of investment funds, „Harvard Business Review” 43, 1965 , nr 1, s. $63-75$.

7 M.C. Jensen, The performance of mutual funds in the period 1945-1964, ,Journal of Finance” 23, 1968 , nr 2, s. 389-416.

8 T. Miziołek, Zysk, ryzyko i koszty — ranking funduszy inwestycyjnych i powierniczych w 1999 roku, „Nasz Rynek Kapitałowy” 2000, nr 7-8; idem, Fundusze akcyjne i zrównoważone — ryzyko i zysk (podsumowanie 2000 roku), „Profesjonalny Inwestor” 2001, nr 10 (2).

9 A. Stanimir, Efektywność i ryzyko funduszy inwestycyjnych, „Prace Naukowe Uniwersytetu Ekonomicznego we Wrocławiu" 2001, nr 915, s. 138-146; E. Majerowska, J. Kowalczyk, Ocena efektywności zarzadzania portfelem na przykładzie wybranych funduszy inwestycyjnych, „Prace Naukowe Uniwersytetu Ekonomicznego we Wrocławiu” 2003, nr 990; P. Jamróz, Efektywność wybranych FIO rynku akcji w latach 2003-2011, „Finanse, Rynki Finansowe, Ubezpieczenia” 2013, nr 63, s. 193-206; P. Sekuła, Analiza stóp zwrotu i ryzyka polskich funduszy akcji, „Prace Naukowe Uniwersytetu Ekonomicznego we Wrocławiu” 2011, nr 158, s.1060-1067; K. Jurek-Wasilewska, op. cit., s. 20-33.

10 J. Czekaj, M. Woś, J. Żarnowski, Efektywność giełdowego rynku akcji w Polsce z perspektywy dziesięciolecia, Warszawa 2001. 
Sharpe'a. W pracy W. Zatonia ${ }^{11}$ natomiast do oceny efektywności wykorzystano współczynnik Modiglianich, który pozwala określić stopę zwrotu funduszu na podstawie ryzyka całkowitego portfela rynkowego.

W drugim podejściu oceny efektywności funduszy inwestycyjnych wykorzystuje się nowoczesne miary efektywności inwestycji, które nie wymagają dodatkowego założenia o normalności (symetrii) rozkładu stóp zwrotu. W tym przypadku wykorzystywane są takie miary, jak współczynnik Omega ${ }^{12}$, współczynnik Sortino $^{13}$ czy też czteroczynnikowy model Carharta ${ }^{14}$. W tych analizach uwzględnia się wpływ również innych rodzajów ryzyka, takich jak wielkość i wartość spółek giełdowych, wartości narażonej na ryzyko oraz negatywnej koncepcji ryzyka. Te nowe miary efektywności do badania polskiego rynku funduszy wprowadzono między innymi w pracy D. Dawidowicz ${ }^{15}$. W 2011 roku z kolei K. Perez ${ }^{16}$ poszerzyła katalog miar efektywności o wskaźnik Sharpe’a-Omega i współczynnik potencjału nadwyżkowej stopy zwrotu. Ocenę efektywności funduszy można przeprowadzić również z poziomu umiejętności zarządzających. W tym przypadku nie ma konieczności tworzenia rankingów między inwestycjami, ponieważ fundusze zostają podzielone na te, w których zarządzający osiągnęli dodatnie stopy zwrotu, oraz te, w których zarządzający uzyskali ujemną stopę zwrotu. Pracami, w których wykorzystano metody oceny funduszy pod kątem umiejętności zarządzających, są między innymi prace J. Olbryśs ${ }^{17}$, M. Homa i M. Mościbrodzkiej ${ }^{18}$ oraz K. Perez ${ }^{19}$ (2012), w których wykorzystano między innymi czteroczynnikową alfę

11 W. Zatoń, Wyznaczanie stóp zwrotu o jednakowym ryzyku w analizie porównawczej inwestycji, na przyktadzie funduszy powierniczych i inwestycyjnych $w$ Polsce, „Prace Naukowe Akademii Ekonomicznej we Wrocławiu" 2001, nr 890, s. 68-74.

12 W. Shadwick, C. Keating, A universal performance measure, ,Journal of Performance Measurement" 6 (3), 2002, s. 59-84.

13 F. Sortino, L. Price, Performance Measurement in a Downside Risk Framework, ,Journal of Investing" 3 (3), 1994, s. 59-64.

14 M.M. Carhart, On persistence in mutual fund performance, „Journal of Finance” 52, 1997, s. $57-82$.

15 D. Dawidowicz, Strategie zarzadzania funduszami inwestycyjnymi a ich wyniki na przyktadzie funduszy inwestycyjnych akcyjnych w 2005 roku, „Folia Universitatis Agriculturae Stetinensis. Oeconomica" 256 (48), 2007.

${ }^{16} \mathrm{~K}$. Perez, Metody oceny efektywności funduszy inwestycyjnych i ich przydatność dla polskich funduszy akcji, [w:] Rynek finansowy w okresie zaburzeń, red. W. Przybylska-Kapuścińska, Poznań 2011.

17 J. Olbryś, Ocena efektywności zarządzania portfelem funduszu inwestycyjnego z wykorzystaniem wybranych wieloczynnikowych modeli market-timing, „Optimum. Studia Ekonomiczne” 2010, nr 4 (48), s. 44-61.

${ }_{18}$ M. Homa, M. Mościbrodzka, Dynamiczne wersje hybrydowych modeli market timing oraz weryfikacja ich przydatności w ocenie ryzyka i efektywności funduszy inwestycyjnych, „Finanse, Rynki Finansowe, Ubezpieczenia” 2016, nr 1 (79), s. 73-85, DOI: 10.18276/frfu.2016.79-05

${ }^{19}$ K. Perez, Efektywność funduszy inwestycyjnych. Podejście techniczne i fundamentalne, Warszawa 2012. 
Jensena z modelu Carharta oraz trójczynnikową alfę w modelu Famy i Frencha, a także zmodyfikowane modele market-timing. Przedstawione podejścia do oceny efektywności funduszy inwestycyjnych nie są tożsame. W pierwszej grupie metod ocenia się (pośrednio) efekty (wyniki) działalności zarządzających, natomiast w drugim badaniu podlegają umiejętności zarządzających. Dopiero połączenie tych dwóch podejść pozwala na dokonanie pełnej oceny wyników funduszy inwestycyjnych. Warto w tym miejscu wspomnieć również o próbach wprowadzenia do badań efektywności funduszy innych metod - taksonomicznych ${ }^{20}$, wnioskowania bayesowskiego ${ }^{21} \mathrm{i}$ analizę falkową ${ }^{22}$.

\section{Efektywność inwestycji - wybrane miary klasyczne i alternatywne}

Poprzez efektywność rozumieć należy rezultat podjętych działań, który w naukach ekonomicznych wyraża się jako relacja efektów do poniesionych nakładów. Taka relacja pozwala więc zweryfikować, czy podjęte inwestycje były efektywne, czyli czy osiągnięte wyniki finansowe były współmierne do poniesionych nakładów. Wśród podstawowych czynników, które działają na efektywność funduszy w literaturze przedmiotu, wskazane są: sytuacja na rynku finansowym, charakter polityki inwestycyjnej, wartość zarządzanych aktywów, a także wyniki uzyskiwane w przeszłości ${ }^{23}$. Warto podkreślić, że ostatnie trzy czynniki należą do czynników bezpośrednio związanych z funduszem.

Podstawową miarą, prezentującą relację pomiędzy zyskiem uzyskanym z inwestycji w dany instrument finansowy a nakładami, jakie zostały poniesione na jego zakup, jest prosta stopa zwrotu $-R(t)$. Nie powinna być ona jednak brana pod uwagę jako miara efektywności zarządzania portfelem, ponieważ nie uwzględnia innych, dostępnych na rynkach inwestycji alternatywnych. W związku z tym do pomiaru efektywności stosuje się nadwyżkowe stopy zwrotu, mianowicie:

- premię za ryzyko (rentowność całkowitą), czyli różnicę między stopą zwrotu uzyskaną przez fundusz a stopą wolną od ryzyka:

$$
r_{f}(t)=R(t)-R_{f}(t)
$$

— dodatkową stopę zwrotu, czyli różnicę między stopą zwrotu uzyskaną przez fundusz a stopą rynkową:

20 M. Homa, M. Mościbrodzka, Application of diagram methods and hierarchical agglomerative procedures to assess the risk of investment funds on the Warsaw Stock Exchange, „Nauki o Finansach" 2016, nr 4 (29), s. 21-34, DOI: 10.15611/nof.2016.4.02.

21 T. Sikora, Analiza wyników funduszy inwestycyjnych w Polsce z wykorzystaniem wnioskowania bayerowskiego, Warszawa 2010.

22 A. Zamojska, Zastosowanie analizy falkowej w ocenie efektywności funduszy inwestycyjnych, „Prace Naukowe Uniwersytetu Ekonomicznego we Wrocławiu” 2015, s. 325-333, DOI 10.15611/ pn.2015.385.35.

${ }^{23}$ K. Perez, Efektywność funduszy inwestycyjnych... 


$$
r_{M}(t)=R(t)-R_{M}(t)
$$

Stopa wolna od ryzyka wyznaczana jest dla bezpiecznych i należących do najbardziej płynnych inwestycji, dostępnych na rynkach. Inwestycjami wolnymi od ryzyka są zwyczajowo bony skarbowe (najczęściej pięćdziesięciodwutygodniowe) lub obligacje Skarbu Państwa. W podobny sposób wyznacza się stopę zwrotu w odniesieniu do rynku, która oparta jest na tak zwanym benchmarku.

Aż do momentu ukazania się pracy Markowitza ${ }^{24}$ inwestorzy oceniali rentowność portfela inwestycji prawie wyłącznie na podstawie osiąganej stopy zwrotu, choć byli świadomi istnienia ryzyka związanego z inwestycją w dane aktywa. Dzięki jego pracy nauczyli się rozpoznawać owo ryzyko w kategoriach zmienności zwrotów. W nowoczesnej teorii portfelowej zakłada się, że optymalna inwestycja polega na maksymalizacji funkcji użyteczności inwestora, która zależy jedynie od średniej i wariancji stóp zwrotu. Na podstawie tej teorii Sharpe (1964), Lintner (1965) i Mossin (1969) ${ }^{25}$ stworzyli model wyceny aktywów kapitałowych (CAPM), wiążący oczekiwaną przez inwestora relację zwrot-ryzyko z ryzykiem rynku, na którym lokowane są dane aktywa i tak powstały statystyczne miary efektywności funduszy, wykorzystujące odchylenie standardowe stóp zwrotu do pomiaru ryzyka, nazywane miarami klasycznymi.

Stosunek Sharpa jest pierwszą miarą efektywności z grupy miar klasycznych, zaproponowaną przez Williama Forsytha Sharpe'a $(1966)^{26}$ :

$$
S R=\frac{\overline{r_{f}}}{\sigma}
$$

Wskaźnik ten określa średnią miesięczną nadwyżkę stopy zwrotu ponad stopę wolną od ryzyka, przypadającą na jednostkę ponoszonego ryzyka, mierzonego odchyleniem standardowym w okresie inwestowania. Inwestorom jako najlepszą przedstawia się inwestycję w fundusz o największej wartości wskaźnika $S R$. Należy jednak podkreślić, że użyteczność tej miary jest znikoma w sytuacjach, gdy na rynku obserwuje się inwestycje w fundusze, które w historycznym okresie inwestowania przyniosły ujemne, średnie stopy zwrotu. Wówczas w wielu przypadkach spośród dwóch tego typu funduszy wskaźnik $S R$ sugeruje wybrać ten, który przynosi znacząco wyższą stratę. Dzieje się tak, gdy fundusz cechuje jednocześnie wyższe odchylenie standardowe stopy zwrotu. Tego typu przypadki prowadzą do zafałszowanego rankingu w jednorodnej grupie funduszy inwesty-

${ }^{24}$ H. Markowitz, Portfolio Selection, „The Journal of Finance” 7 (1), 1952, s. 77-91, DOI: https:// doi.org/10.1111/j.1540-6261.1952.tb01525.x.

25 W.F. Sharpe, op. cit., s. 119-138; J. Lintner, The Valuation of Risk Assets and the Selection of Risky Investments in Stock Portfolios and Capital Budgets, „Review of Economics and Statistics” 1965, 47, 1965, nr 1, s. 13-37, DOI: 10.2307/1926735; J. Mossin, Security Pricing and Investment Criteria in Competitive Markets, „American Economic” 1969, nr 59, s. 749-756.

26 W.F. Sharpe, op. cit. 
cyjnych, w okresach dekoniunktury rynkowej. Tę anomalię można wyeliminować, stosując modyfikację wskaźnika Sharpe’a, zaproponowaną przez Israelsena i daną wzorem ${ }^{27}$ :

$$
S R^{*}=\frac{\overline{r_{f}}}{\sigma_{r_{f}} /\left|\bar{r}_{f}\right|},
$$

Podobnej konstrukcji jest wskaźnik informacji $(I R)$, którego struktura oparta została na relacji oczekiwanej dodatkowej stopy zwrotu do odchylenia standardowego dodatkowych stóp zwrotu ${ }^{28}$ :

$$
I R=\frac{\overline{r_{M}}}{\sigma_{M}}
$$

W przypadku występowania historycznych okresów z ujemnymi stopami zwrotu modyfikacja $I R^{*}$ polega na korekcie mianownika, analogicznej, jak w przypadku wskaźnika Sharpe'a i prowadzi do wzoru ${ }^{29}$ :

$$
I R^{*}=\frac{\overline{r_{M}}}{\sigma_{M}^{\overline{r_{M}} /\left|\overline{r_{M}}\right|}},
$$

Wskaźniki klasyczne wymagają jednak spełnienia założeń dotyczących struktury rynku walorów oraz postaci rozkładu ich stóp zwrotu. Jest to prawidłowe podejście przy założeniu, że rozkład stóp zwrotu jest normalny lub logarytmiczno-normalny. Osłabieniem tego założenia jest przyjęcie, że rozkład stóp zwrotów z inwestycji jest symetryczny. Gdy rozkład stóp zwrotu wykazuje asymetrię, miary klasyczne nie pełnią funkcji miar prawidłowo ukazujących efektywność inwestycji. Asymetria odzwierciedla fakt występowania zbyt dużej liczby pozytywnych lub negatywnych obserwacji w stosunku do średniej w rozkładzie, a więc nienormalny sposób kształtowania się cen z okresu na okres i tym samym ich stóp zwrotu. Analitycy traktują asymetrię rozkładu zwrotów jako instrument wyjaśniania przeszłych zwrotów z inwestycji przewartościowanych lub niedowartościowanych (będących poniżej lub powyżej oczekiwań). Stąd też, jako modyfikację klasycznej miary ryzyka, jaką jest odchylenie standardowe, wykorzystuje się semiodchylenie standardowe ${ }^{30}$ :

$$
s \sigma_{R}=\sqrt{\frac{1}{n-1} \sum_{i=1}^{n}\left[\min \left(R_{i}-\bar{R} ; 0\right)\right]^{2}}
$$

27 C.L. Israelsen, A refinement to the Sharpe ratio and information ratio, „Journal of Asset Management" 5, 2005, nr 6, s. 423-427.

28 J.L. Treynor, B. Fisher, How to Use Security Analysis to Improve Portfolio Selection, „Journal of Business" 46, 1973, nr 1, s. 66-85.

${ }^{29}$ C.L. Israelsen, op. cit.

30 W. Tarczyński, Rynki kapitałowe. Metody ilościowe, Warszawa 1997. 
Na jego podstawie zdefiniowane zostały alternatywne miary efektywności. Pierwszą z nich jest miara Sortino, która została skonstruowana w sposób podobny do współczynnika Sharpe’a z tą różnicą, że w jej budowie bierze się pod uwagę asymetrię badanego rozkładu stóp zwrotu. Miara ryzyka w tym przypadku uwzględnia jedynie straty mierzone stopą zwrotu, mniejszą niż przyjęta wymagana stopa zwrotu. Miara Sortino jest więc stosunkiem zysku wypracowanego ponad pewną minimalną, akceptowalną wartość stopy zwrotu do semiodchylenia standardowego (s $\sigma)$ w odróżnieniu od odchylenia standardowego u Sharpe'a ${ }^{31}$ :

$$
\text { SoR }=\frac{\bar{R}-R_{w}}{s \sigma_{w}}
$$

gdzie $R_{w}$ to minimalna akceptowalna wartość stopy zwrotu (najczęściej jest to 0 lub średnia stopa zwrotu z instrumentu wolnego od ryzyka), natomiast ( $\left.s \sigma_{w}\right)$ to semiodchylenie standardowe, odnoszące się do, to znaczy:

$$
s \sigma_{w}=\sqrt{\frac{1}{n-1} \sum_{i=1}^{n}\left[\min \left(R_{i}-R_{w} ; 0\right)\right]^{2}}
$$

Modyfikacją wskaźnika SoR jest wskaźnik potencjału nadwyżkowej stopy zwrotu $U P R$, w którym licznik uwzględnia nadwyżki ponad próg rentowności i wyraża się on wzorem ${ }^{32}$ :

$$
U P R=\frac{\frac{1}{n-1} \sum_{i=1}^{n} \max \left(R_{i}-R_{w} ; 0\right)}{s \sigma_{w}}
$$

$U P R$ jest więc stosunkiem odchyleń pozytywnych od przyjętej minimalnej akceptowalnej wartości do odchyleń negatywnych. Analogiczna idea była podstawą budowy wskaźnika Omega. Głównym zamysłem twórców tego miernika było podzielenie rozkładu stóp zwrotu z analizowanej inwestycji na dwie części: atrakcyjną oraz nieatrakcyjną, z punktu widzenia oczekiwań inwestora. W tym celu została zastosowana progowa stopa zwrotu, która tworzy granicę wyodrębniającą te dwie części. Wskaźnik Omega wyraża więc stosunek średniej stopy zwrotu powyżej progu rentowności do średniej stopy zwrotu poniżej tego progu ${ }^{33}$ :

$$
\Omega=\frac{\sum_{i=1}^{n} \max \left(R_{i}-R_{w} ; 0\right)}{\left|\sum_{i=1}^{n} \min \left(R_{i}-R_{w} ; 0\right)\right|}
$$

31 F. Sortino, L. Price, op. cit.

32 F. Sortino, R. van der Meer, A. Plantinga, The Upside Potential Ratio, „Journal of Performance Measurement" 4 (1), 1999, s. 10-15.

33 W. Shadwick, C. Keating, op. cit. 
Jego wartość daje informację o średniej, dodatniej nadwyżce ponad minimalną, wymaganą stopę zwrotu, przypadającą na średnią, obliczoną z tych wartości stóp zwrotu, które są mniejsze od minimalnego poziomu. Można zatem stwierdzić, że jest on miarą „rozpiętości” pomiędzy dodatnimi i ujemnymi odchyleniami stóp zwrotu od minimalnej wymaganej stopy zwrotu. Funkcja Omega może być też spostrzegana jako funkcja wypłaty, informująca, dla jakiej wartości stopy procentowej prawdopodobieństwo „wygranej” jest wyższe niż prawdopodobieństwo „przegranej”. Tak więc dla określonej wartości stopy procentowej instrument finansowy z wyższą wartością współczynnika Omega jest atrakcyjniejszy dla inwestora od instrumentu o niższej wartości współczynnika Omega ${ }^{34}$. W przypadku rynku funduszy inwestycyjnych przyjmuje się, że fundusz o wysokiej efektywności to taki fundusz, którego menadżer trafnie przewiduje zmiany w koniunkturze rynkowej, umiejętnie dobiera instrumenty finansowe do funduszu oraz konsekwentnie realizuje założenia dotyczące poziomu ryzyka inwestycyjnego oraz postanowień statutu danego funduszu ${ }^{35}$.

\section{Wyniki badań}

Badaniu poddano stopy zwrotu z dwustu czterdziestu siedmiu funduszy inwestycyjnych o najdłuższym oknie inwestycyjnym (dziesięć lat), notowanych w okresie od grudnia 2008 roku do listopada 2018 według grup:

- AKCJI UNIWERSALNYCH (A) — pięćdziesiąt dwa fundusze inwestycyjne akcji polskich;

— AKCJI MAŁYCH I ŚREDNICH SPÓŁEK (MiS) — dwadzieścia cztery fundusze akcji małych i średnich przedsiębiorstw;

- MIESZANYCH - sześćdziesiąt cztery fundusze mieszane, w tym trzydzieści stabilnego wzrostu (SW), czternaście aktywnej alokacji (MAA),siedem absolutnej stopy zwrotu (ASZ) oraz trzynaście zrównoważonych (Z);

— OBLIGACYJNYCH (O) — trzydzieści dziewięć funduszy inwestycyjnych, w tym dwadzieścia jeden skarbowych (OS) i osiemnaście przedsiębiorstw (OP);

- RYNKU PIENIĘŻNEGO (P) — czterdzieści osiem funduszy inwestycyjnych, w tym pięć funduszy ochrony kapitału (POK) i czterdzieści trzy uniwersalne (PU).

Z każdej z grup funduszy wybrano reprezentanta, którego wyniki były przeciętnymi wynikami, osiąganymi w każdej grupie; ich nazwy wraz z benchmarkiem przedstawiono $\mathrm{w}$ tabeli $1^{36}$.

34 K. Borkowski, Miary efektywności zarządzania na rynkach finansowych, Warszawa 2014, s. 94.

35 K. Perez, Efektywność funduszy inwestycyjnych...

36 W kolejnym kroku badań nad efektywnością analizie zostaną poddane wszystkie fundusze notowane w okresie badawczym. 
Tabela 1. Reprezentanci wraz z ich benchmarkiem

\begin{tabular}{|l|l|l|}
\hline Oznaczenie & \multicolumn{1}{|c|}{ Typ } & \multicolumn{1}{c|}{ Benchmark } \\
\hline A9 & Akcji polskich & $100 \%$ WIG \\
\hline MIS11 & Akcyjne małych i średnich przedsiębiorstw & $90 \%$ sWIG80 + 10\% WIBID 1M \\
\hline ASZ2 & Absolutnej stopy zwrotu & $40 \%$ WIG+60\%TBSP Index \\
\hline MAA6 & Mieszany Aktywnej Alokacji & $50 \%$ WIG + 50\% TBSP Index \\
\hline SW12 & Mieszany Stabilnego Wzrostu & $\begin{array}{l}30 \% \text { WIG + 40\% TBSP Index + } \\
30 \% \text { WIBID 6M }\end{array}$ \\
\hline Z3 & Mieszany Zrównoważony & $\begin{array}{l}55 \% \text { WIG20 + 30\% TBSP Index + } \\
15 \% \text { WIBID 6M }\end{array}$ \\
\hline OP3 & Obligacji Przedsiębiorstw & $100 \%$ WIBID 3M \\
\hline OS11 & Obligacji Skarbowych & $100 \%$ WIBID 6M \\
\hline POK4 & Pieniężny Ochrony Kapitału & $100 \%$ WIBID 1M \\
\hline PU40 & Pieniężny Uniwersalny & $70 \%$ TBSP Index + 30\% WIBID 6M \\
\hline
\end{tabular}

Wyniki funduszy inwestycyjnych zaczerpnięto ze strony portalu inwestycyjnego stooq.pl.

Źródło: opracowanie własne na podstawie analizy.pl.

W związku z tym, że celem badania było zweryfikowanie, czy klasyczne podejście do oceny ryzyka i efektywności inwestycji w przypadku FI w Polsce jest podstawą poprawnego wnioskowania zarówno w krótkim, jak i długim oknie czasowym, w kolejnym kroku zbadano rozkład stóp zwrotu reprezentantów analizowanych funduszy w dwóch oknach czasowych — odpowiednio dziesięcioletnim i rocznym, a wyniki zamieszczono w tabelach 2 i $3^{37}$.

Tabela 2. Statystyki opisowe dla wybranych FI wraz z testem normalności rozkładu — okres 10 lat

\begin{tabular}{|c|c|c|c|c|c|c|c|c|c|c|}
\hline FI & A9 & MIS11 & ASZ2 & MAA6 & SW12 & $\mathrm{Z3}$ & OS11 & OP3 & POK4 & PU40 \\
\hline 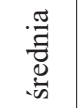 & 0,1691 & 0,0156 & 0,0797 & 0,0074 & 0,0073 & 0,1561 & 0,0822 & 0,0915 & 0,0460 & 0,0852 \\
\hline 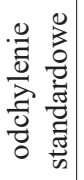 & 2,2373 & 1,7992 & 0,7238 & 1,1904 & 0,9411 & 1,5064 & 0,9256 & 0,5377 & 0,1731 & 0,1122 \\
\hline
\end{tabular}

37 W związku z ograniczeniami artykułu, w pracy pokazano jedynie dwa skrajne okna czasowe. Okna czasowe o długości pomiędzy rokiem a dziesięcioma latami dawały pośrednie wyniki we wnioskowaniu. 


\begin{tabular}{|c|c|c|c|c|c|c|c|c|c|c|}
\hline 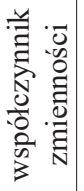 & 13,2340 & 115,670 & 9,0812 & 161,830 & 129,230 & 9,6477 & 11,2650 & 5,8731 & 3,7609 & 1,3181 \\
\hline 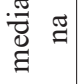 & 0,2283 & 0,2233 & 0,1321 & 0,0767 & 0,0153 & 0,2243 & 0,0698 & 0,0982 & 0,0386 & 0,0863 \\
\hline 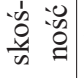 & $-0,5219$ & $-1,0885$ & $-1,4539$ & $-0,6527$ & $-0,0886$ & $-0,6309$ & 0,7321 & 0,0822 & $-0,2431$ & $-0,3278$ \\
\hline 站 & 2,3300 & 4,5327 & 8,5187 & 2,0228 & 4,2615 & 1,8339 & 9,9890 & 22,754 & 4,8849 & 3,3989 \\
\hline in & 0,9705 & 0,9458 & 0,9274 & 0,9735 & 0,9335 & 0,9738 & 0,9680 & 0,7927 & 0,9353 & 0,9466 \\
\hline 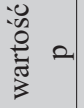 & 0,0000 & 0,0000 & 0,0000 & 0,0000 & 0,0000 & 0,0000 & 0,0000 & 0,0000 & 0,0000 & 0,0000 \\
\hline
\end{tabular}

Źródło: opracowanie własne na podstawie stooq.pl.

Tabela 3. Statystyki opisowe dla wybranych FI wraz z testem normalności rozkładu — roczny okres inwestycji

\begin{tabular}{|c|c|c|c|c|c|c|c|c|c|c|}
\hline FI & A9 & MIS11 & ASZ2 & MAA6 & SW12 & $\mathrm{Z3}$ & OS11 & OP3 & POK4 & PU40 \\
\hline 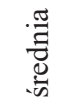 & $-0,2401$ & $-0,4319$ & $-0,3991$ & $-0,2097$ & $-0,0164$ & $-0,0688$ & $-0,0367$ & $-0,0041$ & 0,0206 & 0,0475 \\
\hline 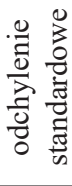 & 2,0020 & 1,978 & 1,0372 & 1,314 & 1,000 & 1,8204 & 0,3509 & 0,0923 & 0,0604 & 0,0649 \\
\hline 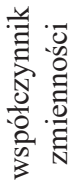 & 8,3369 & 4,5807 & 2,5989 & 6,2667 & 60,7980 & 26,4500 & 9,5506 & 22,5100 & 2,9269 & 1,3667 \\
\hline 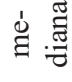 & 0,0109 & $-0,116$ & $-0,2908$ & $-0,116$ & 0,142 & 0,2451 & 0,0079 & 0,0000 & 0,0155 & 0,0522 \\
\hline 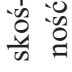 & $-0,2216$ & $-0,8462$ & $-2,3667$ & $-0,3329$ & $-0,2295$ & $-0,3159$ & 0,0434 & $-0,1927$ & 0,2865 & $-0,0654$ \\
\hline 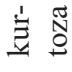 & $-0,4067$ & 2,111 & 10,4420 & $-0,333$ & $-0,824$ & $-0,6914$ & 1,6297 & 0,2866 & 0,9498 & 4,9419 \\
\hline
\end{tabular}




\begin{tabular}{|c|c|c|c|c|c|c|c|c|c|c|}
\hline in & 0,9185 & 0,9468 & 0,8180 & 0,9855 & 0,9692 & 0,9716 & 0,9638 & 0,9873 & 0,9655 & 0,9027 \\
\hline 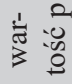 & 0,0000 & 0,0213 & 0,0000 & 0,7751 & 0,1951 & 0,2461 & 0,1140 & 0,8483 & 0,1352 & 0,0005 \\
\hline
\end{tabular}

Wytłuszczone wartości $p$ testu normalności Shapiro-Wilka oznaczają zgodność rozkładu stóp zwrotu z rozkładem normalnym.

Źródło: opracowanie własne na podstawie stooq.pl.

Jak można zauważyć, w okresie dziesięciolecia wszystkie fundusze, niezależnie od strategii inwestycyjnej, osiągnęły dodatnie średnie stopy zwrotu. Największą efektywność według tej miary osiągały fundusze akcyjne, które charakteryzowały się również największą ich zmiennością, mierzoną odchyleniem standardowym, co oczywiście wiąże się z tym, że są to fundusze najbardziej ryzykowne. Warto jednak zaznaczyć, że rozkład stóp zwrotu w żadnym $\mathrm{z}$ analizowanych reprezentantów nie był zgodny z rozkładem normalnym. Co więcej, większość z nich charakteryzowała się lewostronną, silną lub umiarkowaną asymetrią, co świadczyło o osiąganiu przez dane fundusze ponadprzeciętnych, ujemnych zwrotów z inwestycji i jest to bezpośrednie wskazanie nad zasadnością stosowania oceny w oparciu o semiodchylenie. Wraz ze skracaniem okna czasowego w części funduszy inwestycyjnych rozkład stóp zwrotu staje się zgodny z rozkładem normalnym. Jedynie w FI z grupy akcyjnych oraz absolutnej stopy zwrotu, których polityka inwestycyjna jest nastawiona na optymalizację zysków, rozkład stóp zwrotu nie był zgodny z rozkładem normalnym. W przypadku uniwersalnego pieniężnego FI można zauważyć, że pomimo rozkładu stóp zwrotu, niezgodnego z normalnym, fundusz ten charakteryzował się większą koncentracją danych wokół średniej w porównaniu do rozkładu gaussowskiego i jego niezgodność z teoretycznym rozkładem wynikała nie z asymetrii rozkładu, lecz właśnie z leptokurtyzmu (co potwierdza wysoka wartość kurtozy i bliska zeru wartość współczynnika skośności).

Jak można zauważyć, z analizy rozkłady wynika, że w obu oknach czasowych zaburzone zostały warunki niezbędne do poprawnego zastosowania klasycznych miar oceny efektywności. W związku z tym wyznaczono - dla wszystkich funduszy — miary klasyczne i alternatywne służące ocenie efektywności we wskazane inwestycje, charakteryzujące się zróżnicowaną ekspozycją na ryzyko. W związku z tym, że w analizowanych okresach inwestycji część funduszy odnotowała straty (w stosunku do instrumentu bazowego), klasyczne i alternatywne miary zostały skorygowane o ten fakt, zgodnie z propozycją zamieszczoną w pracy C.L. Israelsena ${ }^{38}$. W tabelach 4 i 5 zamieszczono wyniki miar klasycznych $i$ alternatywnych w ocenie długookresowej oraz zgodności ich rankingów.

38 C.L. Israelsen, op. cit.

(C) for this edition by CNS 
Tabela 4. Miary klasyczne i alternatywne efektywności wybranych FI; okres inwestycji 10 lat

\begin{tabular}{|l|l|l|l|l|l|l|l|l|}
\hline \multicolumn{1}{|c|}{ FI } & \multicolumn{1}{|c|}{ SR } & \multicolumn{1}{c|}{ IR } & \multicolumn{1}{c|}{ SoR1 } & SoR2 & UPR 1 & UPR 2 & Omega 1 & Omega 2 \\
\hline A9 & 0,0681 & 0,0913 & 0,1583 & 0,1064 & 0,7416 & 0,6298 & 1,2714 & 1,1949 \\
\hline MIS11 & 0,0348 & $-0,0255$ & $-0,0158$ & 0,0640 & 0,5653 & 0,7010 & 0,9104 & 1,3218 \\
\hline ASZ2 & 0,0586 & $-0,0277$ & $-0,0173$ & 0,0917 & 0,5466 & 0,6079 & 0,8787 & 1,1776 \\
\hline MAA6 & 0,0343 & $-0,0705$ & $-0,0480$ & 0,0510 & 0,4345 & 0,5606 & 0,6201 & 1,0363 \\
\hline SW12 & 0,0670 & 0,1762 & 0,3838 & 0,1005 & 0,3838 & 0,5970 & 0,6670 & 1,1313 \\
\hline Z3 & 0,0729 & 0,1367 & 0,2462 & 0,1303 & 0,7687 & 0,7295 & 1,4711 & 1,2810 \\
\hline OS11 & 0,0491 & $-0,0215$ & $-0,0144$ & 0,0810 & 1,1753 & 0,6251 & 0,7666 & 1,1070 \\
\hline OP3 & 0,0450 & 0,2151 & 0,5745 & 0,0664 & 0,9777 & 0,5534 & 2,4245 & 1,0751 \\
\hline POK4 & 0,0497 & 0,1951 & 0,5257 & 0,0758 & 0,8027 & 0,5744 & 2,8976 & 1,0061 \\
\hline PU40 & 0,0632 & 0,2692 & 0,8999 & 0,0962 & 1,2283 & 0,5806 & 3,7405 & 1,0818 \\
\hline
\end{tabular}

*1 - miara efektywności FI w stosunku do rynku (benchmarku), 2 - miara efektywności FI w stosunku do instrumentu wolnego od ryzyka (dziesięcioletnie bony skarbowe).

Źródło: opracowanie własne na podstawie stooq.pl.

W okresie dziesięciolecia wszystkie fundusze były bardziej efektywne niż inwestycja w instrumenty wolne od ryzyka, o czym świadczą dodatnie wartości wskaźników $S R$ oraz $S o R 2$. Ten wniosek jest odmienny, jeśli porównamy fundusze $\mathrm{z}$ ich rynkiem (benchmarkiem) — w tym przypadku aż czterech z dziesięciu reprezentantów miało efektywność niższą niż rynek, zarówno w kontekście klasycznym, jak i alternatywnym. Na podstawie wstępnej oceny, opartej na klasycznych i alternatywnych miarach z pierwszej grupy, czyli na semiodchyleniu, można stwierdzić, że mierniki te podobnie oceniają efektywność FI. Uwzględnienie w ocenie pozostałych miar alternatywnych (z drugiej grupy) wskazuje jednak już zupełnie inne fundusze jako te bardziej efektywne niż wynikałoby to z klasycznej oceny (tabela 5).

Na podstawie powyższych wyników można wskazać fundusze, które według miar klasycznych są w czołówce funduszy najbardziej efektywnych (na przykład SW12), natomiast uwzględniając asymetrię w ich rozkładzie, ich efektywność jest zdecydowanie niższa niż pozostałych i taki wynik uzyskujemy niezależnie od tego, czy efektywność tę rozważamy w porównaniu z rynkiem, czy też z instrumentem wolnym od ryzyka. Warto podkreślić, że w zestawieniu były brane fundusze o średnich wynikach w grupie. Istnieje podejrzenie, że w przypadku skrajnych reprezentantów te różnice w ocenie, według analizowanych dwóch klas miar, mogłyby się jeszcze bardziej różnicować.

W przypadku rocznego okresu inwestycyjnego liczba funduszy mniej efektywnych, zarówno w porównaniu z rynkiem, jak i z inwestycją w instrumenty wolne od ryzyka, była już zdecydowanie większa niż w długim oknie czasowym. 
Tabela 5. Ranking efektywności FI według miar klasycznych i alternatywnych; okres inwestycji - 10 lat

\begin{tabular}{|l|c|c|c|c|c|c|}
\hline \multirow{2}{*}{ FI } & \multicolumn{2}{c|}{$\begin{array}{c}\text { W stosunku do instrumentu } \\
\text { wolnego od ryzyka }\end{array}$} & \multicolumn{3}{c|}{ W stosunku do rynku } \\
\cline { 2 - 7 } & SR & UPR & Omega & IR & UPR & Omega \\
\hline A9 & 2 & 3 & 3 & 6 & 6 & 5 \\
\hline MIS11 & 9 & 2 & 1 & 8 & 7 & 6 \\
\hline ASZ2 & 5 & 5 & 4 & 9 & 8 & 7 \\
\hline MAA6 & 10 & 9 & 9 & 10 & 9 & 10 \\
\hline SW12 & 3 & 6 & 5 & 4 & 10 & 9 \\
\hline Z3 & 1 & 1 & 2 & 5 & 5 & 4 \\
\hline OS11 & 7 & 4 & 6 & 7 & 2 & 8 \\
\hline OP3 & 8 & 10 & 8 & 2 & 3 & 3 \\
\hline POK4 & 6 & 8 & 10 & 3 & 4 & 2 \\
\hline PU40 & 4 & 7 & 7 & 1 & 1 & 1 \\
\hline
\end{tabular}

Źródło: opracowanie własne na podstawie danych z tabeli 4.

Tabela 6. Miary klasyczne i alternatywne efektywności wybranych FI — roczny okres inwestycji

\begin{tabular}{|l|c|c|c|c|c|c|c|c|c|c|}
\hline \multicolumn{1}{|c|}{ FI } & $\begin{array}{c}\text { Nor- } \\
\text { mal- } \\
\text { ność }\end{array}$ & SR* & IR* & TR & SoR 1 & SoR 2 & UPR 1 & UPR 2 & $\begin{array}{c}\text { Omega } \\
1\end{array}$ & $\begin{array}{c}\text { Omega } \\
2\end{array}$ \\
\hline A9 & - & $-0,4100$ & $-0,0891$ & $-0,1465$ & $-0,0041$ & $-0,0711$ & 0,4120 & 0,5471 & 0,8885 & 0,8806 \\
\hline MIS11 & - & $-0,9643$ & 0,0312 & $-0,3346$ & 0,0145 & $-0,2488$ & 0,7692 & 0,7091 & 1,0799 & 1,0466 \\
\hline ASZ2 & - & $-0,7809$ & $-0,3512$ & $-0,3064$ & $-0,2820$ & $-0,1691$ & 0,2494 & 0,5190 & 0,3675 & 0,7543 \\
\hline MAA6 & + & $-0,2682$ & $-0,0782$ & $-0,1160$ & $-0,0570$ & $-0,0561$ & 0,3703 & 0,4656 & 0,5576 & 0,7095 \\
\hline SW12 & + & 0,0346 & 0,0430 & 0,0866 & 0,0760 & 0,0518 & 0,0760 & 0,6390 & 0,1157 & 1,0220 \\
\hline Z3 & + & 0,0115 & 0,0206 & 0,0350 & 0,0347 & 0,0234 & 0,6625 & 0,8372 & 1,0553 & 1,2047 \\
\hline OS11 & + & 0,0267 & $-0,0364$ & 0,0658 & $-0,0255$ & 0,0436 & 0,2081 & 0,6709 & 0,4768 & 0,9921 \\
\hline OP3 & + & 0,0421 & 0,0386 & 0,0944 & 0,0621 & 0,0660 & 0,4951 & 0,6585 & 1,1435 & 1,0430 \\
\hline POK4 & + & 0,0533 & 0,3139 & 0,1189 & 1,6911 & 0,0831 & 2,1620 & 0,6674 & 4,5905 & 0,8245 \\
\hline PU40 & - & 0,0658 & 0,3038 & 0,1485 & 0,7446 & 0,1119 & 0,9490 & 0,7429 & 4,6422 & 1,1130 \\
\hline
\end{tabular}

Źródło: opracowanie własne na podstawie stooq.pl.

Może to wynikać z faktu, że inwestycje w tego typu instrumenty powinny mieć horyzont inwestycyjny co najmniej dwuletni (w przypadku FI akcji — co najmniej pięcioletni). W ocenie krótkookresowej wyznaczono również miary klasyczne i alternatywne, których wyniki wraz ze zgodnością rankingów przedstawiono w tabeli 6 i 7. 
Tabela 7. Ranking efektywności FI według miar klasycznych i alternatywnych — roczny okres inwestycji

\begin{tabular}{|l|r|r|r|r|r|r|r|c|}
\hline \multirow{2}{*}{ FI } & \multicolumn{4}{|c|}{$\begin{array}{c}\text { w stosunku do instrumentu wolnego } \\
\text { od ryzyka }\end{array}$} & \multicolumn{5}{c|}{ w stosunku do rynku } \\
\cline { 2 - 10 } & SR & SoR & UPR & Omega & IR & SoR & UPR & Omega \\
\hline A9 & 8 & 8 & 8 & 7 & 9 & 7 & 6 & 6 \\
\hline MIS11 & 10 & 10 & 3 & 3 & 5 & 6 & 3 & 4 \\
\hline ASZ2 & 9 & 9 & 9 & 9 & 10 & 10 & 8 & 9 \\
\hline MAA6 & 7 & 7 & 10 & 10 & 8 & 9 & 7 & 7 \\
\hline SW12 & 4 & 4 & 7 & 5 & 3 & 3 & 10 & 10 \\
\hline Z3 & 6 & 6 & 1 & 1 & 6 & 5 & 4 & 5 \\
\hline OS11 & 5 & 5 & 4 & 6 & 7 & 8 & 9 & 8 \\
\hline OP3 & 3 & 3 & 6 & 4 & 4 & 4 & 5 & 3 \\
\hline POK4 & 2 & 2 & 5 & 8 & 1 & 1 & 1 & 2 \\
\hline PU40 & 1 & 1 & 2 & 2 & 2 & 2 & 2 & 1 \\
\hline
\end{tabular}

Fundusze oznaczone kolorem szarym charakteryzowały się gaussowskim rozkładem stóp zwrotu.

Źródło: opracowanie własne na podstawie danych z tabeli 6.

Mimo że w przypadku oceny krótkookresowej część funduszy miała stopy zwrotu o rozkładzie normalnym, to dla wszystkich FI widoczna jest zgodność pomiędzy rankingiem ich efektywności, według miar opartych na odchyleniu standardowym, i tych, które zostały oparte na odchyleniach ujemnych. Można zatem stwierdzić, że w tym przypadku rozkład stóp zwrotu nie determinował zmiany w ocenie efektywności FI. Zaskakujące jest natomiast, że w wypadku miar UPR oraz Omega pozycje rankingowe zmieniły się zarówno w grupie funduszy o normalnym rozkładzie stóp zwrotu, jak i tych, których rozkład stóp zwrotu nie był z nim zgodny. Według literatury przedmiotu przy wykorzystaniu funkcji Omega do oceny atrakcyjności portfeli inwestycyjnych inwestorzy powinni preferować portfele z wyższymi wartościami współczynnika Omega. Portfele charakteryzujące się wyższym poziomem Omega z większym prawdopodobieństwem przyniosą wyższą stopę zwrotu niż stopa bazowa (z rynku lub z inwestycji w instrument wolny od ryzyka) $)^{39}$.

\section{Zakończenie}

Na podstawie uzyskanych wyników można stwierdzić, że efektywność FI na rynku polskim zwiększała się wraz z wydłużeniem okresu inwestycyjnego dla wszystkich analizowanych grup funduszy bez względu na stopień ryzyka inwe-

39 K. Borkowski, op. cit., s. 95. 
stycyjnego, lecz wzrost tej efektywności najbardziej widoczny był dla funduszy akcyjnych, co poniekąd potwierdza słuszność twierdzenia, że zalecany czas trwania dla tego typu inwestycji to co najmniej pięć lat. Z drugiej strony, może to również sugerować, że w przypadku inwestycji „pasywnej” osoby zainteresowane pomnażaniem kapitału powinny skłaniać się ku inwestycjom w FI, obarczonym niższym ryzykiem, ponieważ to one mogą zagwarantować stabilne zyski w długim horyzoncie czasowym. Wniosek ten może być podparty wynikami analizy, dotyczącymi mierników efektywności. W większości rankingów tworzonych na miarach opartych na odchyleniu standardowym oraz semiodchyleniu to właśnie bezpieczne FI wybijały się na czołówkę najbardziej efektywnych funduszy. $\mathrm{Z}$ drugiej strony warto zauważyć, że posługując się alternatywnymi miarami efektywności (UPR czy Omega), rankingi te zmieniały się w istotny sposób, nawet do tego stopnia, że fundusze, które w pierwszej grupie były wiodące, w grupie opartej na miarach UPR czy Omega znajdowały się na najniższych pozycjach, i odwrotnie - FI, którym klasyczne miary obniżały efektywność, według miar alternatywnych zdecydowanie zyskiwały na atrakcyjności. Widoczne jest więc, że pozycje rankingowe funduszy zależą od przyjętych wskaźników efektywności, zwłaszcza w kontekście stosowania jako alternatywy wskaźników opartych na koncepcji maksymalnej straty, co oznacza, że w tym przypadku konieczne jest badanie rozkładów. Rankingi tworzone na podstawie wskaźników klasycznych oraz alternatywnych, opartych na semiodchyleniu, prowadzą natomiast do podobnych wniosków o efektywności FI, niezależnie od własności zgodności z rozkładem normalnym ich stóp zwrotu.

\section{Bibliografia}

Borkowski K., Miary efektywności zarządzania na rynkach finansowych, Warszawa 2014.

Carhart M.M., On persistence in mutual fund performance, „Journal of Finance” 52, 1997.

Czekaj J., Woś M., Żarnowski J., Efektywność giełdowego rynku akcji w Polsce z perspektywy dziesięciolecia, Warszawa 2001.

Dawidowicz D., Strategie zarzadzania funduszami inwestycyjnymi a ich wyniki na przykładzie funduszy inwestycyjnych akcyjnych w 2005 roku, „Folia Universitatis Agriculturae Stetinensis, Oeconomica" 256 (48), 2007.

Grinblatt M., Titman S., Mutual Fund Performance: An Analysis of Quarterly Portfolio Holdings, „The Journal of Business” 62, 1989, nr 3, DOI: 10.1086/296468.

Homa M., Mościbrodzka M., Dynamiczne wersje hybrydowych modeli market timing oraz weryfikacja ich przydatności w ocenie ryzyka i efektywności funduszy inwestycyjnych, „Finanse, Rynki Finansowe, Ubezpieczenia” 2016, nr 1 (79), DOI: 10.18276/frfu.2016.79-05.

Homa M., Mościbrodzka M., Application of diagram methods and hierarchical agglomerative procedures to assess the risk of investment funds on the Warsaw Stock Exchange, „Nauki o Finansach" 2016, nr 4 (29), DOI: 10.15611/nof.2016.4.02.

https://www.analizy.pl/fundusze/edukacja/jak-inwestowac/19107/ile-tak-naprawde-mozemy-zarobic-na-funduszach-inwestycyjnych.html.

Israelsen C.L., A refinement to the Sharpe ratio and information ratio, „Journal of Asset Management" 5, 2005, nr 6.

(C) for this edition by CNS 
Jamróz P., Efektywność wybranych FIO rynku akcji w latach 2003-2011, „Finanse, Rynki Finansowe, Ubezpieczenia" 2013, nr 63.

Jensen M.C., The performance of mutual funds in the period 1945-1964, „Journal of Finance” 23, 1968 , nr 2.

Jurek-Wasilewska K., Efektywność inwestowania w otwartych funduszach inwestycyjnych w Polsce w latach 2001-2010, „Finanse i Prawo Finansowe” 2014.

Kon S.J., Jen F.C., The investment performance of mutual funds: an empirical investigation of timing, selectivity, and market efficiency, „The Journal of Business” 52, 1979, nr 2, DOI: 10.1086/296046.

Lintner J., The Valuation of Risk Assets and the Selection of Risky Investments in Stock Portfolios and Capital Budgets, ,Review of Economics and Statistics” 47, 1965, nr 1, DOI: 10.2307/1926735.

Majerowska E., Kowalczyk J., Ocena efektywności zarządzania portfelem na przykładzie wybranych funduszy inwestycyjnych, „Prace Naukowe Uniwersytetu Ekonomicznego we Wrocławiu” 2003, nr 990.

Markowitz H., Portfolio Selection, „The Journal of Finance” 7 (1), 1952, DOI: https://doi. org/10.1111/j.1540-6261.1952.tb01525.x.

Miziołek T., Fundusze akcyjne i zrównoważone — ryzyko i zysk (podsumowanie 2000 roku), „Profesjonalny Inwestor" 2001, nr 10 (2).

Miziołek T., Zysk, ryzyko i koszty - Ranking funduszy inwestycyjnych i powierniczych w 1999 roku, „Nasz Rynek Kapitałowy” 2000, nr 7-8.

Miziołek T., Trzebiński A.A., Efektywność polskich funduszy inwestycyjnych - przegląd metod i literatury, http://knfpan.pan.pl/images/Fin._110-17_6-T.Miziolek_i_in.pdf.

Mossin J., Security Pricing and Investment Criteria in Competitive Markets, „American Economic” 1969 , nr 95.

Olbryś J., Ocena efektywności zarządzania portfelem funduszu inwestycyjnego z wykorzystaniem wybranych wieloczynnikowych modeli market-timing, „Optimum. Studia Ekonomiczne” 2010, nr 4 (48).

Perez K., Efektywność funduszy inwestycyjnych. Podejście techniczne i fundamentalne, Warszawa 2012.

Perez K., Metody oceny efektywności funduszy inwestycyjnych i ich przydatność dla polskich funduszy akcji, [w:] Rynek finansowy w okresie zaburzeń, red. W. Przybylska-Kapuścińska, Poznań 2011.

Reilly F.K., Brown K.C., Analiza inwestycji i zarzadzanie portfelem, Warszawa 2001.

Sekuła P., Analiza stóp zwrotu i ryzyka polskich funduszy akcji, „Prace Naukowe Uniwersytetu Ekonomicznego we Wrocławiu" 2011, nr 158.

Shadwick W., Keating C., A universal performance measure, „Journal of Performance Measurement" 6 (3), 2002.

Sharpe W.F., Mutual Fund Performance, „Journal of Business” 39, 1966, nr 1.

Sikora T., Analiza wyników funduszy inwestycyjnych w Polsce z wykorzystaniem wnioskowania bayerowskiego, Warszawa 2010.

Sortino F., Price L., Performance Measurement in a Downside Risk Framework, „Journal of Investing" 3 (3), 1994.

Sortino F., van der Meer R., Plantinga A., The Upside Potential Ratio, „Journal of Performance Measurement" 4 (1), 1999.

Stanimir A., Efektywność i ryzyko funduszy inwestycyjnych, „Prace Naukowe Uniwersytetu Ekonomicznego we Wrocławiu" 2001, nr 915.

Tarczyński W., Rynki kapitałowe. Metody ilościowe, Warszawa 1997.

Treynor J.L., Fisher B., How to Use Security Analysis to Improve Portfolio Selection, „Journal of Business" 46, 1973, nr 1.

Studenckie Prace Prawnicze, Administratywistyczne

i Ekonomiczne 32, 2020

(C) for this edition by CNS 
Treynor J.L., How to rate management of investment funds, „Harvard Business Review” 43, 1965, nr 1.

Zamojska A., Zastosowanie analizy falkowej w ocenie efektywności funduszy inwestycyjnych, „Prace Naukowe Uniwersytetu Ekonomicznego we Wrocławiu" 2015, DOI 10.15611/pn.2015.385.35.

Zatoń W., Wyznaczanie stóp zwrotu o jednakowym ryzyku w analizie porównawczej inwestycji, na przyktadzie funduszy powierniczych i inwestycyjnych w Polsce, „Prace Naukowe Akademii Ekonomicznej we Wrocławiu" 2001, nr 890. 